\title{
Implementation of Performance Management in Professional Nursing Program at Hang Tuah School of Health Science (STIKES) Pekanbaru
}

\section{(Case Study)}

\author{
Ennimay \\ Doctoral Program, Human Resource Management, Jakarta State University \\ J1. Rawamangun Muka, RT.11/RW.14, Rawamangun, Jakarta Timur, 13220 \\ Tel: 62-821-7513-653Ｅ Email: Ennimay@yahoo.com
}

Hady Efendy (Corresponding Author)

Education Practice and Academic Consultant

Tel: 62-852-8900-7870Ｅ-mail: efendy_hady@yahoo.co.id

Received: August 23, 2017

doi:10.5296/jmr.v9i4.11886
Accepted: Sep. 29, $2017 \quad$ Published: October 1, 2017

URL: https://doi.org/10.5296/jmr.v9i4.11886

\begin{abstract}
The era of globalization requires business and public organizations have competitive advantage, competitiveness in order to survive the increasingly violent competition. The competitiveness of the organization may only be enhanced if the organization is able to adapt to environmental changes. An organization is required to improve its performance, by applying performance management effectively and efficiently. This research analyzes the implementation of performance management of profession nurse coordinator by using descriptive analysis method with literature study approach and case study. The results of the study show that every problem in the field of eye counseling practice and professional coordination and clinical counselors will hold a meeting and discuss the solution. Problems that cannot be resolved in the field of practice will be discussed with the chairperson of the study program and the eye counselor in a meeting on campus. In this study concluded that
\end{abstract}




\section{Macrothink}

Journal of Management Research ISSN 1941-899X 2017, Vol. 9, No. 4

open communication between professional coordinator, eye counselor, academic counselor and preceptor practice field, facilitate in overcoming any problems found during professional practice activities.

Keywords: Performance management, health science, nurse, nursing, professionalism 


\section{Introduction}

The era of globalization requires business and public organizations have competitive advantage, competitiveness in order to survive the increasingly violent competition. Decision-makers, in their quest for strong companies, are required to change their ways of thinking. In the past they thought only to make a profit, now they have to think strategically. General Karl von Clausewitz in 1831 in his book "On War" says that business is a war.

It is a necessity to increase endurance in order to stay competitive in an increasingly competitive world for every organization. The biggest challenge is to create effective working relationships among all parties, especially business, government and community activities. The core of strong leadership is respect and trust.

The competitiveness of the organization may only be enhanced if the organization is able to adapt to the increasingly volatile environmental changes, to make changes. Besides, an organization is required to be able to improve its performance, by applying performance management effectively and efficiently.

Hang Tuah School of Health Sciences (STIKES) Pekanbaru as a public organization needs to build an adaptive organization culture to change, have a strong commitment and have enough competent human resources for the achievement of organizational goals. All successful organizations must protect their future survival by continually reassessing how they value customers and then designing their business to produce it in the best possible way.

The author tries to perform an analysis of the implementation of performance management in the professional coordinating section of nursing in Hang Tuah School of Health Sciences (STIKES) Pekanbaru. According to the authors of the problems faced by profession nurse coordinator is the gap between the workload of lecturers with the demands of Tri Dharma Perguruan Tinggi which must be implemented by the lecturers.

Profession coordinator nursing responsible in the management of nursing students' professional practice in hospital, community health centers (Puskesmas) and community. This research will focus on how the nurse profession coordinator in managing the implementation of field practice of nurse profession students. This study takes the example of a case study that occurred at the Hang Tuah School of Health Sciences (STIKES) Pekanbaru.

\section{Research Methodology}

This study aims to analyze the implementation of performance management coordinator on profession nurse by using descriptive analysis method through literature study approach and case study. The case study is based on the nurse profession education program at the Hang Tuah School of Health Sciences (STIKES) Pekanbaru during the first and second semester of 2016/2017 and the implementation observations were conducted during the student practice conducted by the Profession nurse Coordinator and the results of the student guidance evaluation. Furthermore, the comparison between the implementation of professional practice of students with Competency Standards to be achieved students and SOP coordinator profession nurse. Researchers describe the technique of data analysis by comparing the 
theoretical basis with practice.

\section{Literature Review}

\subsection{Definition of Performance Management}

Performance Management is a systematic process to improve organizational performance by developing individual and team performance. It is a means of obtaining better results by understanding and managing performance within an agreed framework of planned goals, competency standards and requirements (Armstrong, 2009: 9).

Armstrong (2009: 10) also cites the opinions of Briscoe \& Clause (2008) which provide an understanding of Performance Management as a system through which organizations set work goals, consider performance standards, deliver and evaluate performance, provide performance feedback, consider training and development needs and share the award.

Some opinions about the performance collected by Armstong (2009: 57), among others are:

1. Performance management is a means to get better results from organizations, teams and individuals within an agreed framework in planning goals, objectives and standards (Armstrong \& Murlis, 1994).

2. Essence Performance management is the development of individuals with competence and commitment, working towards achieving shared goals in objectives within organizations that support and encourage their achievements (Lockett, 1992).

3. Performance management is intended to improve the strategic focus and organizational effectiveness by ensuring continuous improvement in individual and team performance (Philpott \& Sheppard, 1992).

4. Performance management is the foundation and driving force behind all organizational decisions, work effort, and resource allocation, according to Costello (1994: 3).

From some opinions above can be concluded that performance management as a process to achieve organizational or individual goals by setting goals, objectives and agreed plans for workers to work effectively and efficiently by ensuring continuous improvement in individual and team performance.

The performance management process is designed to achieve one or more of three main objectives:

a. Encourage the achievement of results. Performance management accelerates business outcomes through goal alignment, size, and sharing of individual, team and organizational performance information.

b. Develop capabilities. Performance management aims at developing organizational and individual capabilities by clarifying roles, competencies, conveying constructive feedback and formally conducting coaching and mentoring.

c. Establish consequences. Performance management determines the different levels of employee performance as a means of determining rewards, either in the form of 
compensation, special assignment, or awards in other forms (Berger \& Berger, 2006: 138). (Kaswan, 2012).

\subsection{Why Performance Management is required}

Goals are something the organization expects to achieve. Organizational goals can include improving customer service, fulfilling market demand, improving product or service quality, increasing competitiveness, and improving organizational performance. Each organization, team, or individual can set its own goals. Achieving the goals of an organization shows the work or work performance of the organization and shows as the performance or performance of the organization (Wibowo, 2016).

The nature of performance management is how to manage all organizational activities to achieve organizational goals that have been set before. The goal of organizational performance management is to enhance organizational capacity-organizational capacity to function effectively. (Armstrong, Michael, 2012). Performance management provides benefits not only to organizations, but also managers, and individuals.

\subsection{Basic Principles of Performance Management}

The basic principles of performance management are strategic, formulate goals, plan, get feedback, make measurements, improve performance, are sustainable, create culture, develop, based on honesty, service, responsibility, feel like play, presence compassion, consensus and cooperation and two-way communication.

Some of the factors that can affect performance include:

1. Personal factors, skills, competence, motivation, commitment

2. Leadership factors, quality of encouragement, guidance, support manager or team leader

3. Team Factors, peer support quality

4. System factors, work systems and facilities are provided by the organization

5. Situational factors, internal and external environmental pressures. (Wibowo, 2016).

\subsection{Performance Assessment Steps}

Performance assessment steps include three stages: 1) establishing work standards, 2) assessing the actual performance of employees according to standards, and 3) providing feedback to employees in relation to their performance. (Dessler, Gary, 2016). Competence is an underlying characteristic of an individual that is associated with the results obtained in a job. Competence as the underlying characteristic of a person and related to the effectiveness of individual performance in his work (Spencer \& Spencer, 1993).

Assessment of the achievement of competence needs to be done objectively, based on the performance of existing employees within the organization, with evidence of their mastery of knowledge, skills, attitudes, and values as a result of learning.

The basic classification of measurement according to Kearns (2005a) there are three namely: 


\section{Macrothink}

Journal of Management Research

ISSN 1941-899X

2017, Vol. 9, No. 4

1. Measurements of activity. This simply records activity levels such as number of training days per employee. They do not assess the quality of the activity, for example the impact of training on performance.

2. Performance Measurement. This examines performance improvements such as contribution terms, productivity and profitability.

3. Measurement of value added. This examines the degree to which it measures the value of a person's contribution beyond the cost of producing it. ROI (return on investment) or measure employee payback can be widely included in this category.

Another classification of measures that can be used for the measurement of service performance, among others are:

1. Productivity indicators, i.e. indicators that focus on the amount of work completed within a given timeframe.

2. Level of utilization, the indicator showing the amount of services available used, such as at the school placement level.

3. Time target, which is an indicator showing the average time required to complete a number of jobs, such as the amount of time it takes to complete an order.

4. Service volume, e.g. number of home improvements completed.

5. Demand / provision of services, i.e. indicators indicating such amount of nursing education as compared to the total population of children.

A variety of performance measures as well as family sizes indicate the possibility of flexibility in its use, which can be selected in accordance with the type of business of each organization. Basically every work unit can determine the size that is relevant and significant for the organization. (Wibowo, 2016).

\subsubsection{Performance Review}

The results of the assessment, review, and evaluation are feedback feed-back on the planning and performance implementation process, as well as for future performance improvement. The review contains a means of reviewing everything that has been done before, whether it is policy, strategy, planning or implementation. The core of management success is the result of an effective review. (Wibowo, 2016).

\subsubsection{Performance Evaluation}

Kreitner \& Kinichi (2001: 300) argue that performance evaluation is an evaluative opinion of the nature, behavior, or achievement as the basis for decisions and personnel development plans. Meanwhile, according to Newstrom \& Davis (1997: 173) is a process to assess the performance of participants, share information and seek mutual solutions to improve its performance.

\subsubsection{Performance Improvement}

Individual, team, or organizational performance can achieve a desirable goal, but do not rule out the possibility not in accordance with the desired. The performance of this performance 
should still be done because of the desired performance is not as expected. With the improvement of performance, expected future organizational goals in the future can be achieved better than ever (Wibowo, 2016). At this writing the authors convey the stages of performance management by (Wibowo, 2016), as follows:

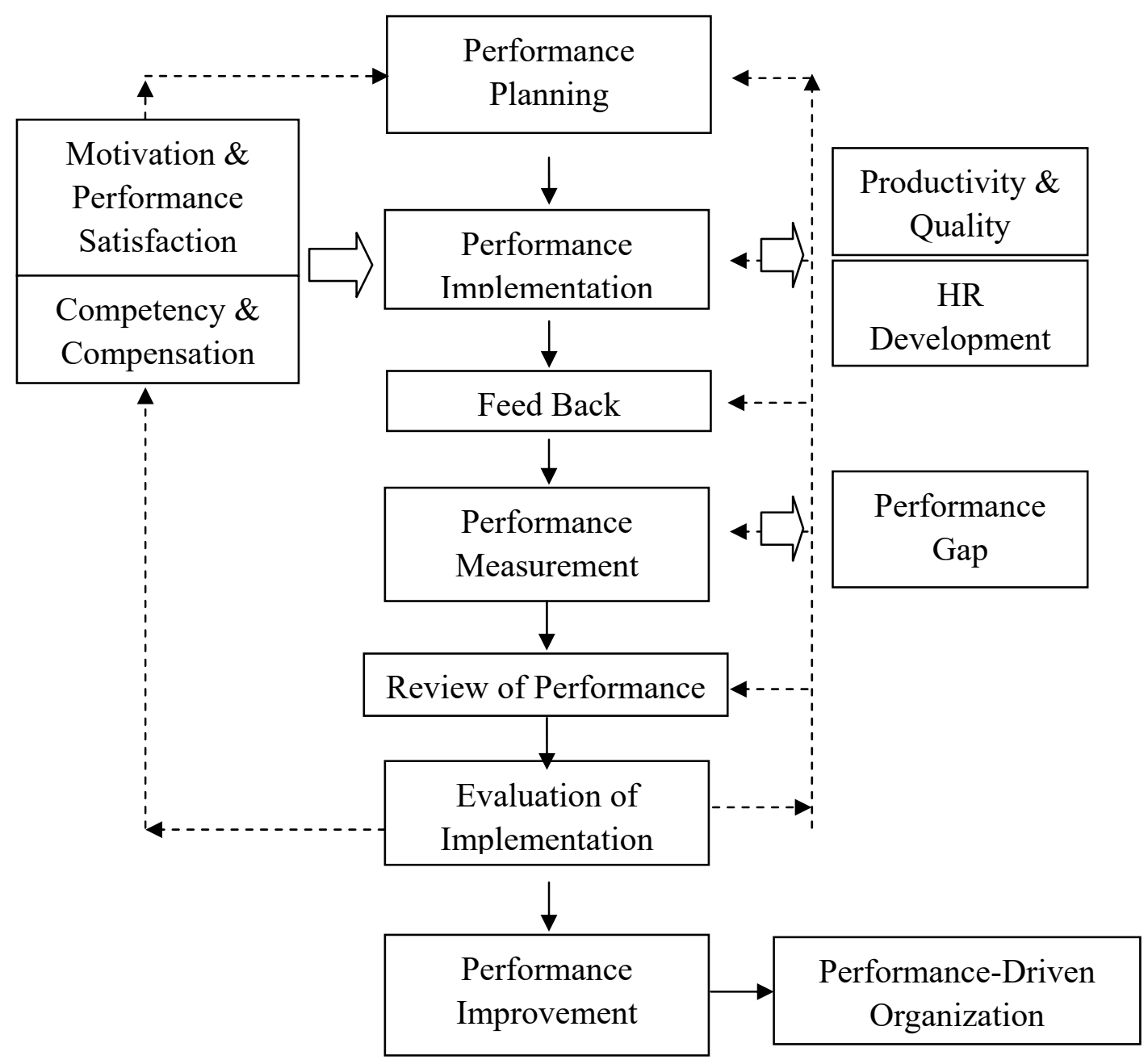

Figure 1. The stages of performance management

Source: Wibowo (2016)

From the scheme above, performance planning consists of strategic management, strategic planning, performance planning, performance goals, performance targets, performance standards and planning tools.

1. Strategic planning is the process of formulating, implementing and evaluating decisions that enable the organization to achieve its objectives. The translation of the strategic plan is to define the vision, mission, goals, objectives, programs, policies, strategies and tactics. 


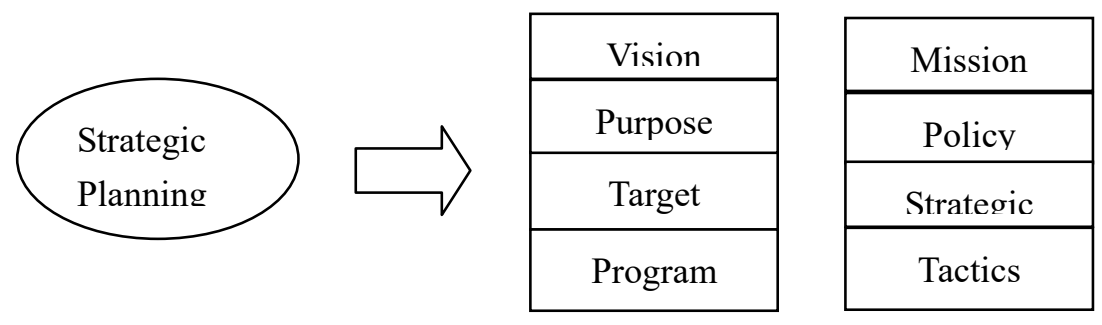

Figure 2. The Strategic Planning

Source: Wibowo (2016)

2. Performance planning; is a process whereby workers and managers work together to plan what workers should do in the coming year, defining how performance should be measured, defining and planning overcoming barriers and gaining mutual understanding of work (Bacal 1999: 54). Managers and individual workers not only need to plan work and performance expectations but also have to choose development activities to improve work skills that workers have at the moment (Wibowo, 2016). Performance plans usually focus on goals within 5 (five) years that reflect key areas of worker responsibility. If this issue has been discussed and agreed upon, then performance goals need to be written in a formal performance plan.

3. Performance goals are the basis for coaching, mentoring and counseling, review progress and final performance evaluations (Wibowo, 2016).

The mission statement is how the organization defines its purpose and articulates its purpose of influencing how people think, behave and act in certain situations (Jerome Hope \& Steve Player in Wibowo, 2016).

Vision is to express a view of what the future of the organization looks like and how it will change the world. The vision must be simple and decisive, put forward in a mission statement. Vision is about the future that is far ahead, while the mission is about now.

Values: organizations need vision and strategy but also need a value system. These values will affect every aspect of corporate culture and can ensure that every worker understands how they behave in every situation (Jonathan Gifford in Wibowo, 2016).

\section{Result and Discussion}

\subsection{Performance Management Application.}

In accordance with the stages of performance management that has been described in the theoretical basis above, the authors try to present the implementation, Performance Management implementation process in Profession Program Nursing in Hang Tuah School of Health Sciences (STIKES) Pekanbaru is as follows:

1. Performance Planning:

Performance planning is a process whereby workers and managers work together to plan 
what workers should do in the coming year, defining how performance should be measured, identifying and planning overcoming barriers and gaining mutual understanding of work (Bacal 1999: 54).

Determination of Vision, Mission, Objectives, and Strategy of Nursing Science Program / Profession Nursing.

\section{A. Vision}

The realization of a leading and leading nursing education center in Riau Province in providing professional nursing services, especially in the prevention of accidents and able to compete in the global market in 2018.

\section{B. Mission}

1. Hold high quality nursing education

2. Conducting research and development in the field of nursing and community service as a manifestation of awareness to improve public health status, especially in the prevention of accidents.

3. Conducting quality assurance consistently and continuously

4. Realizing a conducive academic atmosphere and establishing partnerships with educational institutions and nursing services

5. Establish cooperation both in government institutions, domestic and foreign private.

C. Purpose

a. Produce professional nursing graduates and have good soft skills in providing nursing services accidents

b. Produce works of research that describe the understanding of the basic or scientific principles as a foundation for solving problems in the field of nursing accidents and provide services nursing accidents in the community for the realization of an independent community to live healthy

c. Achieving a consistent and continuous quality assurance

d. Achieving a conducive academic atmosphere through academic performance (Civitas academica and education personnel)

e. Establishment of cooperation with government agencies, private both at home and abroad

D. Target

1. Short Term to 2015

a. Produce graduates with a GPA equal to or greater than 3.00

b. The study period is equal to 4 years for undergraduate program and 1 year for nursing profession program

c. The ability of competent and responsible nursing skills

d. Development of human resources (lecturers) in educational process. 


\section{Macrothink}

2. Mid-Term through 2020

a. Research Development and Community Service

b. Human Resource Development (lecturers)

c. The waiting period alumni $\leq$ with 6 months

d. Strategy of Infrastructure and Funding Facility (in strategic planning / Renstra)

3. Long Term through Year 2025

a. Development of human resources (lecturers) to continue education

b. Cooperation with overseas.

E. Strategy

1. Short-term star:

a. Implement education, teaching and practice referring to the KBK / KKNI curriculum (Indonesia National Qualification Framework)

b. Improvement of objectives, methods, techniques and evaluation of teaching to encourage student activities through two-way teaching and learning process

c. Includes soft skill achievement for students in learning evaluation

d. Cooperate with hospitals, psychiatric hospital (RSJ), PSTW and Community Health Centre (Puskesmas)

e. Improvement of infrastructure in supporting teaching and learning climate

f. Developing yourself continuously to improve graduate professionals

g. Conducting partnerships with various sectors in education

h. Developing the competence of educational personnel by providing training in accordance with the work unit.

2. Medium term strategy

a. Provide good facilities and infrastructure to support "Tri Dharma Perguruan Tinggi" program and its supporters

b. Improve the quality and quantity of research and community service

c. Increase Collaborative research with other universities / national level related institutions

d. Dissemination and transfer of health science and technology

e. Conducting research methodology training activities for new lecturers:

1) Improving research publications through online journals

2) Hold seminars for research publications

3) Provide facilities to lecturers to attend national-level scientific conference

4) Provide facilities to lecturers to attend international scientific conferences.

f. Development of further education for educators through education and degree and non-degree training

g. All lecturers have a nursing master degree classification

h. All lecturers have functional positions of lecturers

i. All lecturers have lecturer certification 


\section{Ml Macrothink}

j. Development of an integrated financial system

k. Develop a nursing laboratory facility

1. Develop library facilities and infrastructure and create an online library.

3. Long-term strategy:

a. Make MOU both nationally and internationally

b. Lecturers already have a doctorate degree of nursing education qualification

c. Produce candidates or graduates of Nursing and nurse degree who are able to think critically and able to perform professional nursing care both in society, and in hospital.

d. Conducting cooperation in the country and abroad.

\subsection{Performance Implementation}

In accordance with Strategic Planning has been the authors described above then in implementation of coordinator nurse profession carry out the following activities: After the students complete the academic education program to obtain a Bachelor degree of nursing (S.Kep), then students continue to step into the professional program: 2 - 6 semesters with 36 credits.

\subsubsection{Profession Nursing Education Course}

During the professional education phase nursing students are required to attend the nursing profession program. Practice This profession program exists in local public hospitals for courses: Basic Nursing Professions (2 credits), Medical Surgical Nursing (6 credits), Child Nursing (4 credits), and Maternity Nursing (3 credits), Emergency Nursing 7 credits), Nursing Management (3 credits), For Nursing Practice (4 credits), Community and Family Nursing (5 credits) and Gerontic Nursing ( 2 credits). So that students must complete the number of SKS $=36 \mathrm{SKS}$ during the professional education program nursing.

During the practice of nursing clinics, students are guided by mentors, namely:

1. Academic counselor, guide 2 - 5 students in one nursing room.

2. The counselor of the nursing room called a preceptor, guiding 2 - 5 students for one ward.

The average academic supervisor and hospital preceptor guides 4 students per room.

\subsubsection{Indicator of student competency achievement:}

To monitor the achievement of competence during student practice using log book. Each competency earned is recorded in the log book, as well as any occurrences beyond the conditions noted. Counselors and students sign every activity undertaken by students. Profession Coordinator get feedback from practice activity of student profession through cooperation between eye counselor and room preceptor.

4.2.3 Obligations of students in the practice area include:

a. The practice of nursing in practice is a clinical activity that must be followed by all students. 
b. Nursing practice consists of practices: medical surgical nursing, nursing, maternity nursing, mental nursing, emergency nursing, nursing management, community nursing, family and gerontics.

c. Each practice ends with exams and graduation from all nursing practice is a prerequisite for completing the professional nursing program.

d. Students who do not follow the clinical practice will be subject to academic sanctions equivalent to sanctions for teaching and learning activities.

e. Nursing practice time: morning: $07.00-15.30 \mathrm{WIB}$, afternoon: $14.00-22.00 \mathrm{WIB}$ and night: 21.00 - 08.00 WIB.

f. Students are required to perform tasks in accordance with the program of each subject and provide reports on academic and field preceptor. For students who do not perform tasks on time will be subject to sanctions set by the coordinator of each subject.

g. Students are responsible for the well-used and well-maintained medical devices, if broken or damaged apparatus are required to replace.

h. Students in carrying out practice in the field of practice must uphold the code of ethics of nursing and maintain the image of nursing education institutions.

\subsubsection{Sanctions}

Sanctions are gradually granted in accordance with the offenses committed:

1. Violation of dress discipline. At this stage the sanctions will be given consisting of: stage I: given a warning and signing a statement of infringement. Stage II: not justified in the relevant practice (absent) on that day and must change on another day and stage III: not given the value of attitude to practice in the room or / place concerned.

2. This attendance disciplinary offense includes a late over 15 minutes considered absentee, one day's absence is renamed 3 days, individual consent permits are replaced as many days are absent and licenses for academic interest are not replaced.

3. Acts of immoral includes excluded from education and for students who are pregnant out of wedlock to submit a letter of resignation from the study program.

4. Negligence in carrying out actions that cause harm and harm to the patient, this includes stage I: Signing a statement of violation, stage II: Settlement with the academic and the hospital and stage III: Not justified the practice of the room or place.

For students who violate this provision imposed sanctions, which is not allowed to take the exam semester. At the end of the room stages, the eye counselor will report student learning outcomes by submitting a written report on all the students do, as well as any violations committed.

\subsection{Discussion}

Professional Coordinators can be aligned with a business unit, functional or departmental level where levels of objectives at this level are linked to organizational goals, targets, and projects to be completed by business units, functions or departments that reflect work. Individual level, the level at which goals are linked to the actors' accountability, key 
outcomes, or tasks reflecting individual job work and focus on the results they are expected to achieve and their contribution to teamwork, department or organizational work.

Task Coordinator Profession among others:

1. Lead and run the guidelines nursing education program and all regulations and policies that have been established.

2. Carry out the tasks assisted by the secretary and treasurer and nursing care counselor.

3. Develop a schedule and matrix guidance practice nursing educational program

4. Monitor and evaluate the implementation of nursing education programs.

Performance Measurement: Each end of the professional coordination stages holds meetings with the subject of counselor, academic counselor and room preceptor to determine the success rate of students in each room stasis. Students are graduated if they have fulfilled all the above requirements with a percentage value of $80-100 \%$.

Performance Review: This performance review is taken in accordance with the Wibowo (2016) approach that Review has the meaning of reviewing everything that has been done before, whether it concerns policy, strategy, planning or implementation. If there is a gap between implementation and the established standard, the professional coordinator immediately holds a meeting between the subject of counselor coordinator, academic counselor and clinical preceptor to discuss the improvements that must be made.

Performance Evaluation: This performance evaluation is taken according to the Kreitner \& Kinichi approach (2001: 300) states that performance evaluation is an evaluative opinion of the nature, behavior, or achievement as the basis for personnel development decisions and plans. Performance evaluation of academic counselor, preceptor and subject of counselor coordinator is done at the end of each semester, by getting input from the guidance students and fellow supervisor team through evaluation format which has been provided by professional program of nursing. Evaluation results from students and co-workers will be presented to each counselor as feedback for future improvement.

Performance improvements: This performance improvement is based on Wibowo's (2016) approach where individual, team, or organizational performance can achieve a desirable objective, but does not rule out what is not. If there is a gap between the established standard and its implementation, then for the next semester, the professional coordinator, the teaching coordinator and the counselor of the practice together with the chairman of the study program hold an evaluation meeting to make improvements.

Learning evaluation system: done regularly by the preceptor both orally and in writing. Preceptor must ensure that student competency achievements are met, visible and corrected in student performance reports (log book). There is also a summative and formative assessment (SOCA / Student Oral Case Analysis) performed once in every phase / subject. There are also DOPS (Direct Observational Procedural Skills) conducted at the end of each stage / subject and added with a student soft skill assessment.

Sanctions: If the student is in trouble in the practice area, the land supervisor will report to the 
teaching coordinator and the teaching coordinator make the report to the professional coordinator in the form of minutes of inquiry (BAP). Sanctions will be awarded to students according to their level of error, as described above. Sanctions that have been set will be submitted to the land of practice in the form of a written letter (such as a certificate of change of service, etc.). The results of the implementation analysis of clinical practice activities of professional students nurse, professional coordinator has been run in accordance with the stages described above.

\section{Advantages:}

1. There are problems in the field of teaching subject coordinator and professional coordinator and clinical guide will hold a meeting and discuss the solution. Problems that cannot be resolved in the field of practice will be discussed with the chairman of the study program and the counselors in the meeting on campus.

2. Each month is a meeting with supervisors, coordinators to monitor student practice activities and review the performance of mentors.

3. At the end of each semester evaluation meetings are conducted with the supervisors, professional coordinators and the head of the study program, to get inputs on the deficiencies that need to be improved and that are in accordance with the standards to be improved.

4. Prior to the next semester, a meeting with all lecturers and education staff of Prodi is held to improve performance against any deficiencies encountered during performance evaluation meetings. Such as improving teaching materials for student practice, equip equipment that still felt less in practice area.

5. Feedback given to improve competence by following training, good performance can motivate lecturers to be more active and feel job satisfaction by getting compensation in the form of reward to follow training and praise from the leadership and there is proposed to get promotion of position.

\section{Deficiency:}

1. There is still a shortage of lecturers and preceptor from the practice area whose education is still $\mathrm{S} 1$ while the requirements of the lecturer should be master degree of nursing. Lecturers in the nurse profession program that is taking the master degree of education as much as 7 people (6 people in University of Indonesia (UI) and 1 person in Jakarta State University (UNJ)).

2. Counselor lecturer position as lecturer of nursing undergraduate students, as a supervisor of professional students and carry out research and community service obligations, so that the overload of teaching $\geq 16$ credits.

3. Preceptor of double occupation practice position as head of nursing room or as nurse of executive in the room which is busy with functional work load of nursing patient in the care room, coupled with other tasks given by the leader. 


\section{Conclusions and Suggestions}

\subsection{Conclusion}

Open communication between professional coordinators, eye counselors, academic counselors and preceptor practice areas, makes it easy to overcome any problems encountered during professional practice activities. All successful organizations must protect their future survival by continually reassessing how they value customers and then designing their business to produce it in the best possible way.

The success of the organization to improve virtually every aspect of its function and approaching the achievement of its vision, there are three basic benchmarks: 1) leadership competence, 2) worker competence, and 3) the extent to which corporate culture reinforces and maximizes competence (Michel Zwell 2000: 9).

\subsection{Suggestion}

To the chairman of Hang Tuah School of Health Science (STIKES) Pekanbaru in order to give opportunity to the lecturers to increase their competence continuously by sending follow education and training outside institution. Send lecturer and student staffs to benchmarks abroad for an overseas learning experience, in line with STIKERS' vision of having an MOU with Escolar University in Manila Philippines.

\section{References}

Arrmstrong, M. (2012). Armstrong's Handbook of Human Resources Management Practice. Ed-12. London: Kogan Page.

Baron, A \& Armstrong, M. (2007). Human Capital Management Achieving Added Value Through People. London and Philadelphia: Kogan Page.

David, F. R. (2012). Manajemen Strategis Konsep. Ed-12, Buku 1. Terj. Dono Sunardi. Jakarta: Salemba Empat.

Dessler, G. (2016). Fundamentals of Human Resource Management. Ed-4. England: Pearson Education.

Kaswan. (2012). Manajemen Sumber Daya Manusia untuk Keunggulan Bersaing Organisasi. Ed-1, Cet-1. Yogyakarta: Graha Ilmu.

Program Studi: S1 Keperawatan dan Profesi Ners. Dokumen/Buku Panduan Akademik Tahun Ajaran 2016/2017. Stikes Hang Tuah Pekanbaru.

Sutrisno, E. (2016). Manajemen Sumber Daya Manusia. Ed-1, Cet-8. Jakarta: Prenadamedia Group.

The Drucker Foundation. (2005). A Leader to leader guide On High Performance Organizations: Organisasi berkinerja tinggi. Editor Frances Hesselbein \& Rob Johnston. Jakarta: Elex Media Komputindo.

Wibowo. (2016). Manajemen Kinerja Ed-5. Jakarta: PT. RajaGrafindo Persada. 
Wibowo. (2016). Budaya Organisasi: Sebuah Kebutuhan untuk Meningkatkan Kinerja Jangka Panjang. Ed-2, Cet-4. Jakarta: PT. RajaGrafindo Persada.

Wahyudi, A S. (1996). Manajemen Strategik; Pengantar Proses Berpikir Strategik. Cet-1. Jakarta: Binarupa Aksara. 